\title{
Effect of semen extenders on the motility and viability of stored African Catfish (Clarias gariepinus) spermatozoa
}

\author{
${ }^{1 *}$ ADEYEMO, OK; ${ }^{1}$ ADEYEMO OA; ${ }^{2}$ OYEYEMI, MO; ${ }^{1}$ AGBEDE, SA \\ ${ }^{1}$ Fish and Wildlife Unit, Department of Veterinary Public Health and Preventive Medicine, University of Ibadan, Ibadan, Nigeria. \\ ${ }^{2}$ Department of Veterinary Surgery and Reproduction, University of Ibadan, Ibadan, Nigeria.
}

\begin{abstract}
This study assessed the effects of common extenders and diluents on the spermatozoa of African catfish (Clarias gariepinus), with the intent of obtaining a semen preservation protocol that can serve as a means of making fingerlings available to fish farmers all year round. Semen samples (milt) were pooled from mature broodstock males and pre-extension qualities were evaluated. Egg yolk, tomato juice and sodium citrate buffers were combined in four different trials and used to preserve obtained semen at temperatures of $5^{\circ} \mathrm{C}$ and $-40^{\circ} \mathrm{C}$ for 8 days and 4 weeks respectively in different trials. Motility indices of extended, preserved, refrigerated and frozen semen were used to analyze the effect of the various combinations. Forward, progressive and rectilinear motion was employed as a significant measurement of the livability of extended sperm cells and the efficacy of the extender solution. The result of the study showed that the buffer (sodium citrate) on its own performed excellently well (sperm motility was $85 \%$ ) in enhancing survival within the first 24-48 hours post extension; Semen extended with $20 \%$ tomato juice gave the best survival rate when stored at $5{ }^{\circ} \mathrm{C}$, because the sperm cells were still viable by day 6 postextension. Extender containing $20 \%$ egg yolk gave $70 \%$ motility while that containing $10 \%$ egg yolk mixed with $10 \%$ tomato juice gave $60 \%$ motility. However, motility decreased progressively as the period of storage increased. The results of the effect of freezing $\left(\right.$ at $\left.-40^{\circ} \mathrm{C}\right)$ on motility revealed that no motility was observed in all the cryopreserved trials except the sample containing $10 \%$ egg yolk and $10 \%$ tomato juice, which recorded $10 \%$ post-thaw motility. @.JASEM
\end{abstract}

Animal protein that is essential for the well being of man is grossly inadequate in most parts of the world, especially the developing countries. It was estimated that over a billion people, a third of the world's people lack good quality protein (Ensminger 1983). About one out of six people in the world is undernourished and most of them live in developing countries where food production is insufficient (USDA 1985). The standard minimum protein body requirement recommended by the FAO is $70 \mathrm{mg}$ /day and of which $35 \mathrm{mg} /$ day must be from animal protein source (FAO 1990). Today, fish contribute less than $1 \%$ of the world's food supply in terms of dietary energy, $5 \%$ of total protein and $14 \%$ of animal protein. In view of the fore-going, the production and consumption of fish must be drastically increased especially in developing countries.

Catfishes are an economically important group of fresh and brackish water fish worldwide. Several species have been successfully introduced in aquaculture (Teugels, 1996), and the African catfish, Clarias gariepinus (formerly C. lazera; Fishelson et $a$ l, 1994), is perhaps the most important one, not only in Africa but also in South East Asia (e.g., Thailand) and in Europe (e.g., The Netherlands). The availability of gametes throughout the year is important to ensure a constant supply of fish. In captivity $\left(25^{\circ} \mathrm{C} ; 12 \mathrm{~h}\right.$ light per day), C. gariepinus gametogenesis is continuous once sexual maturity is reached (Huisman and Richter, 1987). However, whereas females can be stripped of eggs after treatments with carp pituitary extracts (cPE;
Hogendoorn, 1979) or human Chorionic Gonadotropin (hCG; Eding et al, 1982), spermiation and male reproductive behavior do not take place spontaneously (Van Oordt et al, 1987), even after hormonal therapy. To obtain spermatozoa it is necessary to sacrifice male brood fish (Steyn and Van Vuren, 1987) or surgically remove part of their testes (Bart and Dunham, 1990). Storing batches of spermatozoa by cryo-preservation would significantly improve the reproductive potential of male catfish.

Tasty and fast growing catfish are a popular breed both on the fish farms and on the table. However, producing enough fingerlings poses a major problem. Also, increased productivity is directly linked to increase in the number of offspring and their survival rate (Madu et al, 1998). Obtaining genetically superior males as sperm suppliers would contribute immensely to this. The use of such males could be optimized if there is enough facility to preserve their supplied sperm for longer periods, thereby allowing females to be spawned when and where males are not available. Thus there is need for appropriate semen extenders, sperm motility activators, cryo-protectants and freezing protocol. This project therefore assesses the efficacy of readily available semen extenders (egg yolk and tomato juice) for sperm preservation of African catfish at $5^{\circ} \mathrm{C}$ and deep freezing temperature of $-40^{\circ} \mathrm{C}$.

\section{MATERIALS AND METHODS \\ Experimental Fish}


Male broodstocks of Clarias gariepinus weighing between 800-1,500grammes were used for the experiments. The fish were obtained from a reputable fish farm in Ibadan, Oyo State. The male broodstocks were transported to the laboratory of Veterinary Public Health and Preventive Medicine, University of Ibadan in well aerated containers. The choice of males was based on the possession of a well vascularised genital papilla.

Preparation of buffer

About $250 \mathrm{ml}$ of distilled water was heated to boiling point and allowed to cool under running tap water. The preparation of $2.9 \%$ weight/volume $(\mathrm{w} / \mathrm{v})$ of trisodium citrate was then made by using $2 \times 2.9 \mathrm{~g}$ of trisodium citrate. This amount was dissolved in $200 \mathrm{ml}$ flat bottom flask. This solution was then shaken together and allowed to cool for some few minutes. After cooling, the solution was then made up to the $200 \mathrm{mls}$ mark of the flask, using distilled water.
Preparation of Tomato Juice Diluent

Three large sized fresh tomato fruits were washed thoroughly using distilled water and were placed inside a clean sterilized mortar. The pestle was then used to crush the tomato fruits in order to extract the juice. The juice was collected into 6 plastic test tubes, which were then placed inside the centrifuge. The centrifuge was set at 3000 revolutions per minute and left to operate for 10 minutes. The test tubes were later removed and the clear supernatant fluid was decanted into a clean beaker.

\section{Preparation of Egg yolk component}

Freshly laid eggs were washed and disinfected using $70 \%$ alcohol. They were cracked and the yolk was collected into beakers, using an egg yolk separator.

\section{Extender Solutions}

The experiments were performed using varying compositions of diluents as presented in Table 1.

Table 1: Relative composition of various diluents (trials 1,2,3 and 4)

\begin{tabular}{lllll}
\hline TRIAL & Buffer $(\mathrm{ml})$ & Egg yolk $(\mathrm{ml})$ & Tomato juice $(\mathrm{ml})$ & Total \\
\hline 1 & 80 & 10 & 10 & 100 \\
2 & 80 & 20 & 0 & 100 \\
3 & 80 & 0 & 20 & 100 \\
\hline 4 (CONTROL) & 100 & 0 & 0 & 100 \\
\hline
\end{tabular}

\section{Semen Collection}

The male broodstocks of catfish (Clarias gariepinus) were sacrificed by spinal transaction, after which the belly was dissected and the testes removed. Blood clots and other tissues were rinsed away using the sodium citrate solution. The testes were placed in the buffer solution pending the time of semen release. Semen was collected by gently crushing the testis and aspirating the released milt into a $5 \mathrm{ml}$ syringe.

\section{Post Collection Examination}

Pre-extension motility was determined subjectively by mixing 1 drop of fresh semen with 1 drop of distilled water, and this was observed under the microscope using X10 and X40 objective lenses. Only samples with $80 \%$ motility and above were extended and preserved.

Semen-Extender Mixture

The freshly collected semen was carefully aspirated up to the $1 \mathrm{ml}$ mark of a syringe and the seminal volume was dispersed into the $50 \mathrm{ml}$ conical flask containing the prepared diluent. The mixture gives an extension rate of 1 in 50 (1:50). The mixture was then gently shaken together and dispersed into $5 \mathrm{mls}$ storage bottles, labeled accordingly and kept on ice, before transfer to a refrigerator and a freezer set at $5^{\circ} \mathrm{C}$ and $-40^{\circ} \mathrm{C}$ respectively. Daily storage motilities were observed for the refrigerated samples while the cryopreserved samples were examined after a month of storage.

\section{RESULTS AND DISCUSSION}

The results of the determined Pre-extension motility are presented in table 2. Sodium citrate on its own performed excellently well in enhancing survival within the first 24-48 hours post extension. The motility at 24 hours and $5^{\circ} \mathrm{C}$ for the sample extended with $100 \% \mathrm{Na}$ citrate solution was $85 \%$. Extenders containing egg yolk performed fairly well in keeping sperm cells alive within the first 24-24 hours. $10 \%$ egg yolk with $10 \%$ tomato juice gave $60 \%$ motility, while $20 \%$ egg yolk gave $70 \%$ motility (Table 2 ).

Table 2: Characteristics of prediluted semen for all trials

\begin{tabular}{llllll}
\hline PHYSICAL & TRIAL & TRIAL & TRIAL & TRIAL & $\begin{array}{l}\text { MEAN } \\
\text { PROPERTIES }\end{array}$ \\
\multicolumn{1}{c}{1} & \multicolumn{1}{c}{2} & \multicolumn{1}{c}{3} & \multicolumn{1}{c}{4} & $($ SEM) \\
\hline COLOUR & Milky & Milky & Milky & Milky & Milky \\
VOLUME $(\mathrm{ml})$ & 3 & 2 & 1.5 & 2 & 2.125 \\
MOTILITY $(\%)$ & 85 & 90 & 80 & 90 & 86.5 \\
MASS ACTIVITY & +++ & +++ & +++ & +++ & +++ \\
\hline LIVE/DEAD RATIO $(\%)$ & 85 & 90 & 80 & 90 & 86.5 \\
\hline
\end{tabular}


From the motility results in Table 3 , progressive motility decreased as the period of storage increased. Comparatively, the progressive spermatozoa motility recorded after the first 24 hours for the various diluents are $85 \%, 90 \%, 80 \%$ and $90 \%$ for trials $1-4$ respectively, while those recorded for the same diluents by 48 hours post-extension are $60 \%, 70 \%$, $40 \%$ and $85 \%$. By 120 hours post storage, all sperm cells were found to be dead in all the extender solutions that were refrigerated at $5^{\circ} \mathrm{C}$, except the one containing $20 \%$ egg yolk, which showed $5 \%$ motility of sperm cells. The cryopreserved samples did not give favourable results, as motility was not observed in all of the trials except in the sample containing $10 \%$ egg yolk and $10 \%$ tomato juice, which recorded $10 \%$ post-thaw motility.

Table 3: Duration of motility and viability measured for trials $1-4$ stored at $5^{\circ} \mathrm{C}$

\begin{tabular}{rrrrrrrr}
\hline DURATION OF STORAGE (DAYS) & 1 & 2 & 3 & 4 & 5 & 6 & 7 \\
\hline DURATION OF STORAGE (HOURS) & 0 & 24 & 48 & 72 & 96 & 120 & 144 \\
Motility (\%) TRIAL 1 & 85 & 60 & 30 & 10 & 0 & 0 & 0 \\
TRIAL 2 & 90 & 70 & 40 & 20 & 15 & 5 & 0 \\
TRIAL 3 & 80 & 40 & 10 & 0 & 0 & 0 & 0 \\
\hline TRIAL 4 (CONTROL) & 90 & 85 & 65 & 10 & 0 & 0 & 0 \\
\hline
\end{tabular}

The mean pre-extension motility value recorded for this work is $86.5 \%$ with a range of $80-90 \%$. This value is in agreement with the suggested preextension motility of $80 \%$ and above (Akcay et al., 1995; Urbanyi et al., 1999). Although various extender solutions have been used to improve sperm storage, results have indicated that sperm motility and viability vary widely. For example, semen of Shortnose sturgeon diluted with commercial salt solutions (Hank's medium and Mounib's medium) could be kept in the refrigerator for a maximum of 6 days, but the spermatozoa exhibited only $31 \%$ motility (Wayman and Tiersch, 2000). In the present study, Semen extended with $20 \%$ tomato juice gave the best survival rate when stored at $5^{\circ} \mathrm{C}$, as the sperm cells were still viable by day 6 post-extension with $5 \%$ motility. This agrees with the work of Wani et al, 1978 and Parandaker, 1991 who observed that $10-20 \%$ yolk level was optimum for the successful storage of buck semen at $3-6^{\circ} \mathrm{C}$. They also got a 40 $50 \%$ conception with a single dose of semen extended with $20 \%$ egg yolk level. However, such species differences are in consonance with the observations of Goskov and Davy, (1994) who reported that there are differences in the degrees of resistance of different livestock semen to extension and freezing.

Table 4: Motility and Viability Measured For Trials 1- 4 Stored At $-40^{\circ} \mathrm{C}$ One Month after Cryo-Preservation

\begin{tabular}{lc}
\hline $\begin{array}{l}\text { DURATION OF STORAGE } \\
\text { (MONTHS) }\end{array}$ & ONE \\
\hline Motility (\%) TRIAL 1 & 10 \\
TRIAL 2 & Nil \\
TRIAL 3 & Nil \\
\hline TRIAL 4 (CONTROL) & Nil \\
\hline
\end{tabular}

Tomato juice alone and in combination with egg yolk gave the most rapid decline in the percentage motilities of the spermatozoa. Thus it may be inappropriate for use in catfish semen extension unlike the positive results obtained by Mann (1964) when he used tomato juice to extend semen collected from men. Another major finding from this study is that sodium citrate can serve very well when there is a need for short preservation of Clarias gariepinus semen, provided it is refrigerated at $5^{\circ} \mathrm{C}$. Sodium citrate provide $65 \%$ motility after 72 hours of storage. This confirms the assertions of Lardy and Philips (1940) and Foote (1980) that physiological buffers have the ability to dilute semen and maintain its viability for some days when refrigerated. This means sodium citrate compares favorably with commercial semen extenders (Hanks balanced salt solution and Mounib's solution), which have been reported to preserve refrigerated semen for up to six days when percentage motility was usually between 20-35\% (Wayman and Tiersch, 2000). Motility duration of up to 9 minutes was also obtained for sodium citrate, which was better than the 2-4 minutes motility duration obtained by Ginzburg (1972), after he activated sperm motility by diluting semen in water.

The poor results obtained following cropreservation in this study can be adduced to the submission of Mazur (1977) and Watson (1995), that successful cryopreservation depend not only on the right choice of cryoprotectant and extender, but also on the freezing protocol used. Cryoprotectant and freezing rate together determine the damage to spermatozoa due to intracellular ice crystallization. However, the $10 \%$ post-thaw mobility obtained with the sample cryopreserved with $10 \%$ egg yolk lends some support to the publications of Lardy and Philips (1940) and Mayer and Lasley (1945) concerning the ability of egg yolk to serve in prolonging spermatozoa survival 
due to its membrane stabilizing and moderate cryoprotective abilities.

\section{REFERENCES}

Akcay, E; Tekin, N; Secer, S (1995). Preservation of Fish Semen. Ege University, J. Fish. Aquat. Sci. 12: $367-373$

Bart, AN; Dunham, RA (1990). Factors affecting survival of channel catfish after surgical removal of testes. The Progressive Fish-Culturist 52:241246.

Eding, EH; Janssen JAL; Kleine Staarman, GHJ; Richter CJJ (1982). .Effects of human chorionic gonadotropin on maturation and ovulation of oocytes in the catfish Clarias lazera (C \& V). In: Richter CJJ, Goos HJTh (ed), Proc Intern Symp Reprod Physiol Fish, Wageningen, The Netherlands, Aug 1982.195 abstr

FAO (1990). Utilization of tropical foods. Annual products compendium on technological and nutritional aspects of processing and utilization of tropical foods, both animal and plants for purposes of training and field reference.

Fishelson, L; Van Vuren, JHJ; Tyran, A (1994). Ontogenesis and ultrastructure of seminal vesicles of the catfish, Clarias garieninus. J Morpho1. 219:59-71.

Foote, RH (1980) Reproduction in Farm Animals (E.S.E. Hafez, e.d.), $4^{\text {th }}$ edition, pp521-545. Lea and Febiger, New York.

Ginzburg, AS (1972). Fertilization in fishes and the problem of polyspermy. Translated from the Russian by Z. Blake. (Available from the National Technical Information Service, TT 7150111, Spring-field,Virginia.)

Guskov, AM; Davy, GY (1994). Reproduction function of farm animals as influenced by stress. Russian Agricultural Sciences. 2: 20-22.

Hogendoorn, H (1979). Controlled propagation of the African catfish, Clarias lazera (C\&V). I. Reproductive biology and field experiments. Aquaculture 17 (4): 323-333.

Huisman, EA; Richter CJJ (1987). Reproduction, growth, health control and aquacultural potential of the African cattish, Clarias garieninus (Burchell 1822). Aquaculture 63:1-14.
Lardy, HA; Phillips, AH (1940). A yolk-buffer pabulum for the preservation of bull semen. Journal of Dairy Science XXXIII: 399-404

Madu, CT; Ita, EO; Omorinkoba,WS; Pandogari, A (1998). How to make more mudfish. African Farming and Food Processing Journal Pp.41-43.

Mann, T (1964) Biochemistry of semen and of the male reproductive tract. Methuen and Co. London Ltd.

Mayer; L (1945). The factor in egg yolk affecting resistance, storage potentials and fertilizing capacity of mammalian spermatozoa. Journal of Animal Science, 4: 261-269.

Mazur, P (1977). The role of intracellular freezing in the death of cells cooled at supraoptimal rates. Cryobiology 14:251-272.

Parandakar, K (1991). Preservation of buck semen at $3^{\circ} \mathrm{C}-5^{\circ} \mathrm{C}$. Marathwada Agriculture University, Parbani.

Steyn, GJ; Van Vuren, JHJ (1987). The fertilising capacity of cryopreserved sharptooth cattish (Clarias gariepinus) sperm. Aquaculture; 63:187193.

Teugels, GG (1996). Taxonomy, phylogeny and biogeography of catfishes (Ostariophysi, Siluroidei): an overview. Aquat Living Resources 9: 9-34.

Urbanyi, B; Horvath, A; Varga, Z; Horvath, L (1999). Effect of extenders on sperm cryopreservation of African catfish, Clarias parieninus (Burchell). Aquaculture Res.,30:145-151.

Van Oordt, PGWJ; Peute, J; Van den Hurk, R; Viveen WJAR (1987). Annual correlative changes in gonads and pituitary gonadotropes of feral African catfish, Clarias gariepinus. Aquaculture, 63:27-41.

Watson, PF (1995). Recent developments and concepts in the cryopreservation of spermatozoa and the assessment of their post-thawing function. Reprod. Fertil. Dev. 7:871-891.

Wayman, WR; Tiersch, TR (2000). Research methods for cryopreservation of sperm. In: Cryopreservation in Aquatic Species (ed. by TR Tiersch \& PM Mazik), 